International Journal of Linguistics, Literature and Translation

ISSN: 2617-0299 (Online); ISSN: 2708-0099 (Print)

DOI: $10.32996 /$ ijllt

Journal Homepage: www.al-kindipublisher.com/index.php/ijltt

IJLLT

\title{
Investigating Teachers' Views on writing Errors Made by Saudi University Students
}

\author{
Dr. Mohammed Adam Abdul Rahman \\ Assistant Professor, English Department, College of Art and Sciences, King Khalid University, Saudi Arabia
}

$\square$ Corresponding Author: Dr. Mohammed Adam Abdul Rahman, E-mail: moosman@kku.edu.sa

\section{ARTICLE INFORMATION}

Received: 17 October 2021

Accepted: 08 November 2021

Published: 30 November 2021

DOI: 10.32996/ij|lt.2021.4.11.12

\section{KEYWORDS}

Writing errors, writing, error analysis

\section{ABSTRACT}

This study aimed to investigate the most frequent errors made by Saudi university students in writing. The study adopted the descriptive-analytic research method. The data of the study was collected from a questionnaire distributed to a sample of 100 English language teachers at Jazan University, King Saud University, and King Khalid University. The above-mentioned tool satisfied the criteria of validity and reliability. The findings revealed the low abilities of the students in understanding and using syntactical rules properly which was reflected in the enormous number of grammatical errors made by the respondents in the test. Wrong tense errors, prepositions, articles errors were found to be the most frequent ones. The findings also revealed that negative transfer from the mother tongue language is one of the major causes of most of the syntactical errors made by the students in the written text. In light of the study findings, several recommendations were suggested by the researcher that could lead to reducing errors made by students in writing and improve students' writing abilities.

\section{Introduction}

Saudi EFL learners encounter many problems in learning English. They learn English in their native country, where Arabic is the native language. Strevens (1980:25) states that "In Saudi Arabia, EFL learners live in a country where English is not the medium of communication. English is not needed for survival or to be able to enter the job market, therefore learning occurs in a very low acquisition environment. English is not used in this society except in a few businesses or organizations. Consequently, students are not motivated to learn English because they do not see the need for learning it; they mostly study English as a required subject in school or for the fun of speaking a second language. Likewise, Alfallaj (1998:16) indicates that in a society as conservative and closed as that of Saudi Arabia, it has been very difficult for people to accept the idea that a language other than Arabic can be taught to Muslims. People fear that teaching a foreign language might result in students adopting the culture and values of that language. Therefore, Saudi EFL students normally learn English through formal instruction, i.e. inside the classroom where the English Language teachers are native speakers of Arabic, i.e Saudis, Sudanese, Egyptians, Jordanians, etc. Students' opportunity to learn English in a natural atmosphere through direct interaction with native English speakers, is very limited. This is possible only when students encounter native English speakers who come to the country as pilgrims or expats.

Writing is a complex skill and even considered by many linguists as the most difficult of all the four skills (Corder \& Allen, 1974, p.177). It is difficult for both native and non- speakers. However, writing is a real problem for most EFL learners, such as Saudi learners. The source of difficulty arises from the fact that non-native speakers think in their own native language (Arabic) when they write in English. Since good knowledge of grammar is one of the basic requirements of effective writing, learners must acquire proper use of grammatical rules and structures.

\subsection{Objectives of the Study}

This study aims to investigate the most frequent errors made by Saudi university students in writing and to identify their main causes.

Copyright: (C) 2021 the Author(s). This article is an open access article distributed under the terms and conditions of the Creative Commons Attribution (CC-BY) 4.0 license (https://creativecommons.org/licenses/by/4.0/). Published by Al-Kindi Centre for Research and Development, London, United Kingdom. 


\section{Literature Review}

\subsection{Types of Errors}

Corder (1967:28) distinguishes between two types of errors: performance errors and competence errors. He states that "it would be more valuable to treat errors of performance as 'mistakes' because they are not affecting the language learning process, and to use the term error for the systematic(competence) errors of the learner from which his knowledge of the language to date can be affected". In the same vein, Norrish (1983:8) maintains that a mistake is an infrequent derivation that occurs just at certain times and can be corrected by the learner himself. Richards et. al (1985:95) points out that the mistake is made by a learner when writing or spelling unintentionally due to fatigue, carelessness...etc. Performance errors are non-systematic mistakes. They are minor deviations of the language and therefore they are not given much attention by error analysis, since they reveal nothing about the real status of the learner's language knowledge. They include the lapses and slips of the tongue and pen. The student commits these mistakes not because he doesn't know how to use the language, but because maybe he is in a hurry, or under stress, or careless. These mistakes are committed by both native speakers and second language learners and they do not show the level that reveals whether the learner has mastered the target language or not. Competence errors, on the other hand, are serious mistakes because they are systematic. These types of errors are referred to as competence errors. They reveal the extent of knowledge of the target language that was mastered by the learner. They also show the areas of weakness that need more reinforcement. As regarding correction, performance errors can be self-corrected by the learner himself, unlike competence errors which cannot be corrected by the learner alone, and therefore, they need more effort from both the teacher and the learner.

\subsection{Sources of Errors}

According to Brown (1980), the most recurrent sources of errors Brown are interlingual transfer, intralingual transfer, the context of learning, and communication strategies used by learners. James. Likewise, James (1998) classifies errors according to their sources into four types and he added what he called induced errors.

An interlingual transfer which is also referred to as mother-tongue influence causes errors that mainly occur due to mother tongue interference. They are very common at the early stages of the target language based on the learner's only previous knowledge of the first language system. Brown ( 1980: 173). indicates that when one is learning L3, L4, etc., the transfer takes place from all the previously learned languages but the degree of transfer is variable (1980: 173). Intralingual negative transfer, on the other hand, is one of the main sources of errors made by second language learners. They are considered learning strategy errors. According to James (1980: 185) there are seven types of intralingual errors as learning-strategy based errors and lists 7 types of them:

i) False analogy: This refers to the learner mistakenly thinking that a new item behaves like another item already known to him or her. For example, the learner already knows that babies is plural from baby, so he or she thinks that *childs is plural from child*This incorrect analysis indicates that the learner has formed an unfounded hypothesis in the $L 2$ and is putting it into practice.

ii) Incomplete rule application: It occurs when the learner doesn't use all the rules necessary to apply in a particular situation. In fact, it is the converse of overgeneralization.

iii) Exploiting redundancy: This appears in the use of unnecessary morphology, and intelligent learners try to avoid those items which they find redundant to make their learning and communication easier. The opposite of exploiting redundancy is overelaboration which is usually observable in more advanced learners.

iv) Overlooking concurrence restrictions: It means that the learner doesn't know that certain words go together with certain complements, prepositions, etc. An example given by James (1998: 186) is when the learner doesn't understand that the verb to practice is followed by a gerund and not an infinitive.

v) Hypercorrection: It refers to the learners over-monitoring their L2 output".

vi) Overgeneralization: It refers to the use of one member of a set of forms also in situations when the other members must be used. This usually leads to overuse of one form and underuse of the others. Well-known candidates for overgeneralization are pairs as other/another, much/many, some/any, etc. (James 1998: 187) - the learner uses one of them instead of distinguishing between them and using each in the appropriate situation. Overgeneralization of language rules is also common, e.g. *Will he can speak to? reflects that the learner overgeneralizes the use of auxiliary verbs in questions.

\subsection{Review of previous Studies}

A number of studies have been conducted to determine the most common types of errors made by learners in writing. Attia (1990) conducted a study on errors made by Sudanese EFL learners in the use of prepositions. In his study, Attia investigated three types of errors: omission, redundancy, and replacement errors. The study shows that more than $53 \%$ of the errors were 
replacement errors and $23.3 \%$ were omission errors and about the same percentage were redundancy errors. The prepositions that more frequently omitted are 'of', 'to', 'in', 'for', 'at', 'up' and 'with'.It was observed that redundancy and omission errors were mostly committed in the context of prepositional verbs. According to the study, these errors are caused by interlingual and intralingual factors.

Khaoural (2002) conducted a research study to find out grammatical, syntactical, and lexical errors in English composition of English major students of Rajabhat Institute Nakhon Pathom. For grammatical aspects, errors found were: tenses, prepositions, determiners, and verbs. For syntactical aspects, errors found were: contraction form, incomplete sentence structure, compound sentences, word order, and punctuation. For lexical aspects, errors found were: spelling, translating from Thai to English, overgeneralization of translating, and using general lexical items. The findings showed that the first three causes of errors were: the lack and incomplete application of restricted rules, L1 interference, and false hypotheses. The results suggested that most of the students transferred their native language rule patterns into their English writings.

\section{Research Methodology}

The analytic descriptive method was adopted in the study. The quantitative data of the study were analyzed through using the Statistical Packages for Social Sciences (SPSS). Descriptive statistics such as mean and standard deviation were used to test the variability of the scores of the respondents as shown in the results.

\subsection{Population of the study}

The population of the present study consisted of 100 English teachers at Jazan University, King Saud University, and King Khalid University. Most of them have been working in Saudi Arabia for more than five years.

\subsection{Instrumentation}

The researcher designed a questionnaire as the instrument for conducting this study as shown below:

\subsubsection{The Teachers' Questionnaire}

The aim of the questionnaire used in this study was to gather teachers' views about the most common grammatical errors made by students in writing. The questionnaire was administered to a total of 100 ELT teachers at Jazan University, King Saud University, and King Khalid University. It is made of two parts: The first part contains the participants' personal information. The second part consists of sixteen statements investigating the teachers' views related to the questions of the research. A five-point Likert scale was used to show the responses of the participants.

\section{Discussion of the ELT Teachers' Questionnaire items:}

The items of the questionnaire cover the domains below:

Domain (1) Causes of grammatical errors made by students in their composition writing.

This domain is measured by the following statesments:1,2,3 and 4 .

Question 1. What are the possible causes of grammatical errors made by Saudi university students?

Statement 1: Mother tongue interference (Arabic) is one of the main causes of grammatical errors made by Saudi students.

The following tables show, in numbers and percentages, the respondents answer to the statements:

Table (4.2) shows the frequency and percentage for the ELT teachers' responses to statement1

\begin{tabular}{|l|l|l|l|l|l|}
\hline Options offered & $\begin{array}{l}\text { Strongly } \\
\text { agree }\end{array}$ & Agree & Not sure & Disagree & $\begin{array}{l}\text { Strongly } \\
\text { disagree }\end{array}$ \\
\hline No. & 52 & 37 & 9 & 2 & 0 \\
\hline Percentage & $52 \%$ & $37 \%$ & $9 \%$ & $2 \%$ & $0 \%$ \\
\hline
\end{tabular}

As shown in table (4.2) above that 52 of the total respondents strongly agree that mother tongue (Arabic) interference is one of the main causes of grammatical errors made by Saudi students. This number represents the majority of the respondents and the highest percentage of $52 \%$. The same view is supported by another 37 respondents whereas the number of those who disagree is only 2 and 9 show uncertainty. The view that negative transfer from the mother tongue language is one of the main factors behind errors made by learners in grammar is relevant to the findings of many research studies. For instance, Beardsmore (1982:22) states that "Many of the difficulties a second language learner has with grammar are due to the interference of habits from the first 
language. The formal elements of the $L 1$ are used within the context of the $L 2$, resulting in errors in $L 2$, as the structures of the two languages are different.".

Statement 2: Saudi university students' motivation towards learning the English language.

Table (4.3) Frequency and percentage for ELT teachers' responses to statement 2

\begin{tabular}{|l|l|l|l|l|l|}
\hline Options offered & Very high & High & Not sure & Low & Very low \\
\hline No. & 4 & 21 & 8 & 51 & 16 \\
\hline Percentage & $4 \%$ & $21 \%$ & $8 \%$ & $51 \%$ & $16 \%$ \\
\hline
\end{tabular}

Table (4.3) shows that 51 of the total respondents agree that Saudi university students' motivation towards learning the English language is low. This number represents the majority of the respondents and a higher percentage of $51 \%$. The same view is supported by another 16 respondents. The number of those who disagree with the view that Saudi students' motivation is low is 25 whereas 8 show uncertainty.

Statement 3: To what extent do you think Saudi university students are aware that some English grammatical rules have no equivalent in Arabic.

Table (4.4) Frequency and percentage for ELT teachers' responses to statement 3

\begin{tabular}{|l|l|l|l|l|l|}
\hline Options offered & Very aware & Aware & Not sure & Not aware & Not at all aware \\
\hline No. & 4 & 20 & 21 & 47 & 8 \\
\hline Percentage & $4 \%$ & $20 \%$ & $21 \%$ & $47 \%$ & $8 \%$ \\
\hline
\end{tabular}

As seen from the table (4.4) above that 47 of the total respondents agree that Saudi university students are not aware that some English grammatical rules have no equivalent in Arabic. This number represents the majority of the respondents and a percentage of $47 \%$. The same view is supported by another 8 respondents. The number of those who disagree with the view that Saudi students are not aware that some English structures have no equivalent in Arabic is 24 whereas 21 respondents have shown uncertainty. This is in line with what was stated by Ellis (2008), errors reflect gaps in a learner's knowledge; they materialize since a learner is not aware of the correct rule or structure.".

Statement 4: Saudi university learning environment negatively affects learning the English language.

Table (4.5) Frequency and percentage for ELT teachers' responses to statement 1

\begin{tabular}{|l|l|l|l|l|l|}
\hline Options offered & $\begin{array}{l}\text { Strongly } \\
\text { agree }\end{array}$ & Agree & Not sure & Disagree & $\begin{array}{l}\text { Strongly } \\
\text { disagree }\end{array}$ \\
\hline No. & 18 & 25 & 13 & 28 & 16 \\
\hline Percentage & $18 \%$ & $25 \%$ & $13 \%$ & $28 \%$ & $16 \%$ \\
\hline
\end{tabular}

As shown in table (4.5) above shows that 28 of the total respondents strongly disagree that the Saudi university learning environment negatively affects learning the English language. This number constitutes the majority of the respondents, with the highest percentage of $28 \%$. This percentage is supported by another 16 respondents. This view, however, is approved by the number of 18 respondents who strongly agree that the Saudi environment negatively affects English learning. A number of 13 respondents show uncertainty.

To sum up domain (1), it can be said that, in the light of the teachers' responses, most of the grammatical errors made by students in writing originate from the influence of negative transfer as one of the most effective factors in syntactical errors made by Saudi students besides other less influential factors. It could be claimed on the basis of these results, that the hypothesis that L1transfer could be behind grammatical errors made by Saudi university students, is confirmed.

Domain (2): Types of Grammatical Errors made by Saudi University Students

This domain is measured by the statesments:5,6,7 and 8 as shown below:

Question 2. What are the most common types of grammatical errors students make in composition writing?

Statement 5: From your teaching experience, the wrong use of tenses is one of the common grammatical errors. 
Table (4.6) Frequency and percentage for ELT teachers' responses to statement 5

\begin{tabular}{|l|l|l|l|l|l|}
\hline Options offered & $\begin{array}{l}\text { Strongly } \\
\text { agree }\end{array}$ & Agree & Not sure & Disagree & $\begin{array}{l}\text { Strongly } \\
\text { disagree }\end{array}$ \\
\hline No. & 41 & 45 & 10 & 2 & 2 \\
\hline Percentage & $41 \%$ & $45 \%$ & $10 \%$ & $2 \%$ & $2 \%$ \\
\hline
\end{tabular}

It is obvious in the table (4.6) above that 45 of the total respondents agree that the wrong use of tenses is one of the common grammatical errors made by Saudi students in writing. This number represents the majority of the respondents as the highest percentage of $45 \%$. The same view is supported by another 41 respondents, whereas the number of those who disagree with this view is only 2.

Statement 6: From your teaching experience, misuse of the subject-verb agreement rule is one of the common grammatical errors.

Table (4.7) Frequency and percentage for ELT teachers' responses to statement 6

\begin{tabular}{|l|l|l|l|l|l|}
\hline Options offered & $\begin{array}{l}\text { Strongly } \\
\text { agree }\end{array}$ & Agree & Not sure & Disagree & $\begin{array}{l}\text { Strongly } \\
\text { disagree }\end{array}$ \\
\hline No. & 36 & 55 & 4 & 4 & 1 \\
\hline Percentage & $36 \%$ & $55 \%$ & $4 \%$ & $4 \%$ & $1 \%$ \\
\hline
\end{tabular}

Table (4.7) reveals that over 55 of the total respondents agree that misuse of the subject-verb agreement rule is one of the common grammatical errors. This number represents the majority of the respondents as the highest percentage of $55 \%$. The view is disapproved by 4 respondents and 4 as uncertain.

Statement 7: From your teaching experience, omission of the third person singular marker is one of the common grammatical errors.

Table (4.8) Frequency and percentage for ELT teachers' responses to statement 7

\begin{tabular}{|l|l|l|l|l|l|}
\hline Options offered & $\begin{array}{l}\text { Strongly } \\
\text { agree }\end{array}$ & Agree & Not sure & Disagree & $\begin{array}{l}\text { Strongly } \\
\text { disagree }\end{array}$ \\
\hline No. & 24 & 57 & 11 & 6 & 2 \\
\hline Percentage & $24 \%$ & $57 \%$ & $11 \%$ & $6 \%$ & $2 \%$ \\
\hline
\end{tabular}

Table (4.8) above reveals that over 57of the total respondents agree that omission of the third person singular marker is one of the common grammatical errors. This number represents the majority of the respondents as the highest percentage of $57 \%$. A number of 8 show disagreement whereas 11 respondents recorded as uncertain.

Statement 8: From your teaching experience, the misuse of prepositions is one of the common grammatical errors.

\section{Conclusions}

Generally, it could be concluded that the low performance of the students in the writing test revealed that the respondents lack the ability of understanding and use syntactical rules properly. The findings of the study revealed clearly that the wrong tense errors followed by prepositions and verb to be errors are the most recurrent syntactical errors made by the respondents in the study as shown by the results of the respondents in the writing test. They also revealed that negative transfer from the mother tongue was found to be one of the main causes of syntactical errors made by the students in their written texts.

Since wrong tense errors are the most frequent errors in this study, more attention should be paid to grammatical errors particularly tenses, using more effective ways of stressing tenses in meaningful and interesting texts. Teachers should be more aware of the different types of errors made by their students and provide the necessary follow-up work to check the problem areas and provide suitable solutions. Moreover, it is important for teachers to establish what an error is, to be aware of the possible sources of errors, to explain why they occur because a full knowledge of the causes of errors enables the teacher to work out more effective teaching strategies to deal with them. Furthermore, students need to be encouraged to look critically and analytically at their written texts and try to find out the grammatical errors by themselves and correct them. In addition, the English language syllabus and course textbooks should include more free and controlled writing exercises that could help improve students' abilities in both grammar and writing. 
The findings of this study could be applicable to have a common view on all undergraduates in Saudi Arabia. Consequently, it sheds light on designing curricula for the better fulfillment of the teaching and learning of EFL. The ultimate objective of this study is to assist in providing a guiding light to the teachers, the syllabus designers as well as future researchers to pursue this line of research.

\section{References}

[1] Alfallaj, F. S. (1998). An Evaluative Study of Teaching English as a Foreign Language at the Junior College of Technology in Buraydh. Indiana, Indiana University of Pennsylvania.

[2] Arter, J.A., Spandel, V., Culham, R. (2000). Portfolio for Assessment and Instruction. Eric Digest. ED388890.

[3] Bataineh, R. F. (2005). Jordanian Undergraduate EFL Students' Errors in the Use of the Indefinite. Asian EFL Journal, March 2005, Volume 7.Issue 1,Article5

[4] Bereiter, C. \& Scardamalia, M. (1987). The psychology of written composition. Hillsdale, NJ: Lawrence Erlbaum Associates.

[5] Chen,H.C.(1998). A contrastive analysis of the language errors made by the Chinese students of English as a second/foreign language.JournalofWu- FengAppliedLinguistics, 6,224-237.

[6] Chen, C. Y., \& Huang, H. Y. (2003). L2 acquisition of subject-prominence by EFL students in Taiwan. English Teaching\& Learning, 27(4), 99122.

[7] Chen, H. C. (2000). Error analysis of some features of English article usage.Journal ofWu-Feng Applied Linguistics, 8, $282-296$.

[8] Chuo, I. (2001). Mother tongue use in foreign language classrooms: A survey of teachers' and students' perception. Journal of the College of Liberal Arts, NCHU, 31, 199-218.

[9] Corder, S.P. (1967). The significance of learners' errors.Reprinted in J.C.Richards (ed.)(1974,1984) Error Analysis: Perspectives on Second

[10] Language Acquisition.London: Longman, 19-27(Originally in International Review of Applied Linguistics, 5(4).

[11] Corder, S.P. (1971). Idiosyncratic dialects and error analysis. IRAL,9(2), 147-160.

[12] Corder, S.P. (1974). Error Analysis.Ind. P.B.Allen and S.Pit Corder (eds.) Techniques in Applied Linguistics (The Edinburgh Course in Applied Linguistics:3), London: Oxford University Press (Language and Language Learning), 122-154.

[13] Diab, N. (1996). The transfer of Arabic in the English writings of Lebanese Students. RetrievedJanuary5,2003from http://lael.pucsp.br/especialist/181diab.ps.pdf

[14] Fallahi, M. (1991). Contrastive linguistics and analysis of errors, Vol. 1: The grammatical structure of English and Persian. Tehran: Iran University Press.

[15] Fang, Y.C. (1999). Teaching English verb tenses to Chinese EFL students. Journal of Kuen-Shan Institute of technology, 2,119-123.

[16] Farooq, M.U. (1998). Contrastive and error analysis-based teaching strategies. Aichi Women's Junior College

[17] Habash, Z. (1982). Common Errors In The Use of English Prepositions In The Written Work Of UNRW A Student At The End of the Preparatory Cycle

[18] Handrickson. (1979). A Developmental Analysis of English Errors made by Iranian Students: The study made by Henning (1978) at the University of California.

[19] Hedge, T. (1998). Writing: Resource Book for Teachers. Oxford: Oxford University Press.

[20] Henning, G.H. A Developmental Analysis of Errors of Adult Iranian Students of English as a Foreign Language." Language Learning, 28, 2(1978): 387- 397.

[21] Huang, J. (2002). Error analysis in English teaching: A review of studies. Journal of Chung-San Girls' Senior High School,2,19-3

[22] Jain, M.1974.'ErrorAnalysis: Source, CauseandSignificance'.In Richards, J. (Ed.).Error analysis: Perspectives on Second Language Acquisition. 189-215.Essex: Longman.

[23] James, C. (1998) Errors in Language Learning and Use.London: Longman.

[24] Jarvis, S. (2000). Methodological rigor in the study of transfer: IdentifyingL1 influence in 